\title{
Acidisphaera rubrifaciens gen. nov., sp. nov., an aerobic bacteriochlorophyll-containing bacterium isolated from acidic environments
}

\author{
Akira Hiraishi, ${ }^{1}$ Yukiko Matsuzawa, ${ }^{1}$ Toshio Kanbe $^{2}$ and Norio Wakao ${ }^{3}$
}

Author for correspondence: Akira Hiraishi. Tel: +81 532 446913. Fax: +81532446929. e-mail: hiraishi@eco.tut.ac.jp

1 Department of Ecological Engineering, Toyohashi University of Technology, Toyohashi 441-8580, Japan

2 Laboratory of Medical Mycology, Nagoya University School of Medicine, Nagoya 466-8550, Japan

3 Department of Bioscience and Technology, Iwate University, Morioka 020-8550, Japan
Four strains of aerobic, mesophilic, acidophilic bacteria that produced bacteriochlorophyll (BChl) a were isolated from acidic hot springs and mine drainage. The characteristics of the four isolates were almost identical. The isolates were strictly aerobic and chemo-organotrophic. They were Gramnegative, non-motile cocci and coccobacilli, formed salmon-pink colonies on solidified media and produced BChl $a$ and carotenoids only under aerobic growth conditions. The cells also produced small amounts of zinc-substituted BChl a when grown in the presence of $1 \mathrm{mM}$ zinc sulfate. Anaerobic growth in the light was not found, but aerobic growth was stimulated by continuous incandescent illumination. The isolates grew in a pH range of 3.5-6.0, with pH optima of 4.5-5.0. A phylogenetic analysis based on $16 \mathrm{~S}$ rDNA sequences showed that the isolates clustered in the major acidophilic group of the class Proteobacteria, which includes species of the genera Acidiphilium and Rhodopila. The anaerobic phototrophic bacterium Rhodopila globiformis was the closest relative to the new isolates ( $95 \%$ level of sequence similarity). The $\mathrm{G}+\mathrm{C}$ content of the genomic DNA of the isolates was $69 \cdot 1-69 \cdot 8 \mathrm{~mol} \%$. On the basis of these results, it was concluded that the four isolates should be classified into a new genus and a new species, for which the name Acidisphaera rubrifaciens is proposed. The type strain is strain $\mathrm{HS}^{-\mathrm{AP3}^{\top}}$ ( = JCM 10600').

Keywords: Acidisphaera rubrifaciens, acidophilic bacterium, aerobic BChl-containing bacterium, phylogeny, zinc-bacteriochlorophyll

\section{INTRODUCTION}

Obligately aerobic bacteria that have bacteriochlorophylls (BChls) and photochemical activity are categorized into a group of aerobic phototrophic or aerobic BChl-containing bacteria. Most of these bacteria have been classified as members of new genera of the class Proteobacteria, including Erythrobacter, Erythromicrobium, Porphyrobacter, Roseobacter, Roseococcus and Sandaracinobacter (for reviews, see Shimada, 1995; Yurkov \& Beatty, 1998). Recently, several new genera including Craurococcus, Paracraurococcus (Saitoh et al., 1998), Roseovarius

Abbreviations: $\mathrm{BChl}$, bacteriochlorophyll; $\mathrm{Mg}-\mathrm{BChl}$, magnesium-chelated $\mathrm{BChl} ; \mathrm{Zn}-\mathrm{BChl}$, zinc-chelated BChl.

The DDBJ accession numbers for the $16 \mathrm{~S}$ rDNA sequences determined in this study are D86512 and D86513.
(Labrenz et al., 1999), Rubrimonas (Suzuki et al., 1999), Roseateles (Suyama et al., 1999), Roseivivax (Suzuki et al., 1999) and 'Citromicrobium' (Yurkov et al., 1999) have been described as aerobic BChlcontaining bacteria. While most of these genera consist of neutrophilic species, the genus Acidiphilium includes species of aerobic phototrophic acidophiles that inhabit strongly acidic mineral environments such as mine drainage (Kishimoto et al., 1995). Interestingly, the main photopigment of Acidiphilium species is bacteriochlorophyll $a$ chelated with zinc (Zn-BChl $a$ ) in place of magnesium as the central metal (Wakao et al., 1996; Hiraishi et al., 1998). Zn-BChl $a$ is more stable than $\mathrm{Mg}-\mathrm{BChl} a$ under acidic conditions (Wakao et al., 1996; Kobayashi et al., 1998). Thus, it is of major concern to determine whether the occurrence of $\mathrm{Zn}-\mathrm{BChl} a$ in aerobic BChl-containing bacteria is related to the acidic environments of their natural habitats. 
During surveys of acidophilic phototrophic bacteria in various acidic environments, we isolated several strains of pink- to red-pigmented aerobic acidophiles that produced $\mathrm{Mg}$-BChl $a$ but not $\mathrm{Zn}-\mathrm{BChl} a$. Aerobic acidophilic bacteria that contain Mg-BChl $a$ as the main photopigment have not been reported. This article, therefore, describes the taxonomic characteristics of the new aerobic $\mathrm{Mg}$-BChl-producing acidophiles and their phylogenetic relationship to other acidophilic phototrophs. Here we propose to classify the new isolates as a new genus and species with the name Acidisphaera rubrifaciens.

\section{METHODS}

Bacterial strains. Four strains designated HS-AP3 ${ }^{\mathrm{T}}$ (superscript $\mathrm{T}=$ type strain), HS-AP4, HS-AP16 and YO-704 were studied. Strains HS-AP3 ${ }^{\mathrm{T}}$ and HS-AP4 were isolated from surface water and sediment from an acidic hot spring, respectively, in Hakone, Kanagawa Prefecture, Japan. The $\mathrm{pH}$ of the water at the sampling site was $3 \cdot 2$ and the temperature was $32{ }^{\circ} \mathrm{C}$. Strain HS-AP16 was isolated from sediment in an acidic hot spring stream $\left(\mathrm{pH} 2 \cdot 8,35^{\circ} \mathrm{C}\right)$ in Unzen, Nagasaki Prefecture, Japan. Strain YO-704 was isolated from acidic mine drainage $\left(\mathrm{pH} 2 \cdot 5,22^{\circ} \mathrm{C}\right)$ in Iwate Prefecture, Japan. Acidiphilium cryptum ATCC $33463^{\mathrm{T}}$, Acidiphilium rubrum ATCC $35905^{\mathrm{T}}$ and Rhodopila globiformis DSM $161^{\mathrm{T}}$ were used as the reference organisms. The strains with ATCC and DSM numbers were obtained from the American Type Culture Collection, Manassas, VA, USA, and from the DSMZ (Deutsche Summlung von Mikroorganismen und Zellkulturen), Braunschweig, Germany.

Growth media and cultivation. Unless otherwise noted, GNYS medium (pH 4.5) was used for cultivation of the new isolates. This medium consisted of a mineral base (RM2; Hiraishi \& Kitamura, 1984), $0 \cdot 3 \%$ sodium gluconate as the sole carbon source and $0 \cdot 1 \%$ yeast extract as the growth factor. Gluconate and other components of the medium were autoclaved separately and combined before use. The medium contained $0.8 \%$ gellan gum (Wako Pure Chemicals) when used as a solidified medium (Kishimoto \& Tano, 1987). For cultivation of Acidiphilium species, GYS medium (Hiraishi et al., 1998) was used. All aerobic bacteria tested were grown aerobically on a reciprocal shaker at $30{ }^{\circ} \mathrm{C}$ in darkness or under incandescent illumination at 2000 lx. $R$. globiformis was grown anaerobically in the light with $10 \mathrm{mM}$ fructose and $10 \mathrm{mM}$ gluconate as carbon sources, as described by Pfennig (1974). For chemical and genetic tests, cells were harvested by centrifugation from a culture at the late-exponential phase of growth, washed twice with sterile $50 \mathrm{mM}$ phosphate buffer $(\mathrm{pH} 6.8)$ and pelleted. The cell pellets were used immediately for analysis or stored at $-20{ }^{\circ} \mathrm{C}$ until analysed.

Microscopic studies. General cell morphology was studied under an Olympus phase-contrast microscope. Gram staining was performed with a Gram stain reagent kit (Nakarai Tesque). Electron microscopy of the negatively stained cells and thin sections was performed with a JEOL electron microscope as described previously (Hiraishi et al., 1991, 1995b).

Photopigment analysis. A portion of washed cells was resuspended in $50 \mathrm{mM}$ phosphate buffer $(\mathrm{pH} 7 \cdot 0)$, sonicated for $3 \mathrm{~min}$ and centrifuged to remove unbroken cells and large debris. Absorption spectra of the resultant cell extracts were recorded with a Shimadzu BioSpec 1600 spectrophotometer. BChl $a$ was extracted from washed cells with acetone:methanol $(7: 2, \mathrm{v} / \mathrm{v})$ and its concentration was estimated spectrophotometrically by using the absorption coefficient $75 \mathrm{mM}^{-1} \mathrm{~cm}^{-1}$ at $770 \mathrm{~nm}$ (Clayton, 1963). Also, lipid extracts were analysed using silica-gel TLC and spectrochromatography as described previously (Hiraishi et al., 1998). Mg-BChl $a$, Zn-BChl $a$ and spirilloxanthin purified from $A$. rubrum ATCC $35905^{\mathrm{T}}$ were used as the standard photopigments.

Quinone analysis. Quinones were extracted, fractionated and analysed by spectrochromatography as described previously (Hiraishi et al., 1996).

Physiological and biochemical tests. Precultures grown in GNYS medium in darkness were used for all phenotypic tests. Effects of $\mathrm{pH}$ on growth were studied with GNYS medium modified by replacing half of the amount of gluconate with $\mathrm{D}$-xylose. The $\mathrm{pH}$ of the medium was adjusted by adding $1 \mathrm{~N} \mathrm{NaOH}$ or $\mathrm{H}_{2} \mathrm{SO}_{4}$. Carbon nutrition tests were performed with mineral medium RM2 supplemented with $0.05 \%$ yeast extract as the basal medium, to which a neutralized, filter-sterilized carbon substrate was added. The concentration of carbon substrates used was $0.2 \%$ unless otherwise noted. The test tubes were incubated for 2 weeks before the final reading and growth was estimated turbidimetrically by comparing the optical density, at $660 \mathrm{~nm}$ $\left(\mathrm{OD}_{660}\right)$, of the test tubes with that of the control tube without an added carbon source. The optical density in the test tubes was measured directly with a Pharmacia Novaspec spectrophotometer. All other physiological and biochemical tests were performed as described previously (Wakao et al., 1994), GNYS medium being used as the basal medium ( $\mathrm{pH}$ $5 \cdot 5)$ in most cases.

DNA base composition and DNA-DNA hybridization. Genomic DNA was extracted and purified by the method of Marmur (1961). The DNA base composition $(\mathrm{G}+\mathrm{C}$ content) was determined using the HPLC method (Katayama et al., 1984; Hiraishi et al., 1991). DNA-DNA hybridization studies were performed using the quantitative dot-blot hybridization method with biotin labelling and colorimetric detection as reported previously (Hiraishi et al., 1991).

$16 \mathrm{~S}$ rDNA sequencing and phylogenetic analysis. The $16 \mathrm{~S}$ rDNA fragments that corresponded to positions 8-1543 of Escherichia coli 16S rRNA (Brosius et al., 1978) were amplified directly from cell lysates by the PCR as described previously (Hiraishi et al., 1994). PCR products were purified by the PEG precipitation method (Hiraishi et al., 1995a), sequenced directly with a SequiTherm Long-Read Cycle sequencing kit (Epicentre Technologies) and fluorescent primers and analysed with a Pharmacia DNA sequencer. PCR products were also subcloned with a SureClone Ligation kit (Pharmacia), according to the manufacturer's instructions, then sequenced. Sequence data were compiled with the GENETYX-MAC program (Software Development). Multiple alignment of sequence, calculation of the corrected evolutionary distance based on Kimura's two-parameter model (Kimura, 1980) and construction of a phylogenetic tree by the neighbour-joining method (Saitou \& Nei, 1987) were performed with the CLUSTAL W program (Thompson et al., 1994). Branching patterns of trees were evaluated by bootstrapping with 1000 resamplings (Felsenstein, 1985). Alignment positions with gaps and unidentified bases were excluded for the calculations. The tree was illustrated by using the TREEVIEW program (Page, 1997). 


\section{RESULTS}

\section{Enrichment and isolation}

Test tubes containing either GNYS or GYS medium were inoculated with hot-spring water, hot-spring sediment or mine-drainage samples and incubated aerobically on a reciprocal shaker at $30{ }^{\circ} \mathrm{C}$ in darkness. While all GYS tubes gave negative results for pigmented growth, some GNYS tubes gave a pink colour after 1-4 weeks incubation. Subsequent transfers on to solidified media of the same composition resulted in the appearance of tiny pink or salmon-pink colonies, some of which were then purified after repeated streak culturing. Five pigmented isolates thus obtained were designated HS-AP3 ${ }^{\mathrm{T}}$, HS-AP4, HS-AP16 and YO-704 (for their sources, see Methods).

\section{Morphology and ultrastructure}

Cells of the four isolates were cocci and coccobacilli measuring $0.7-0.9 \mu \mathrm{m}$ in width and $1.0-1.6 \mu \mathrm{m}$ in length (Fig. 1). They occurred singly or in pairs and reproduced by binary fission. Motile cells were not observed at any growth stage. Transmission electron microscopy revealed that negatively stained cells of the isolates had no flagella. The Gram reaction was negative.

Ultrathin-section electron microscopy indicated that cells of strain HS-AP3 ${ }^{\mathrm{T}}$ had the ultrastructure typical

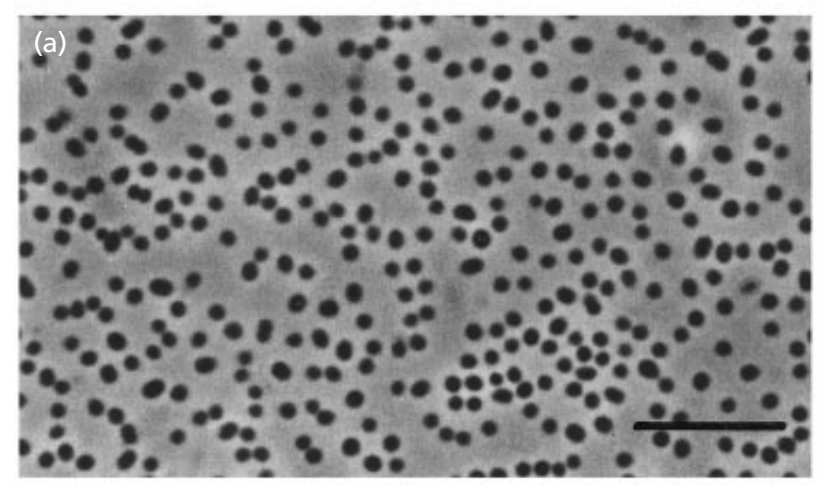

(b)

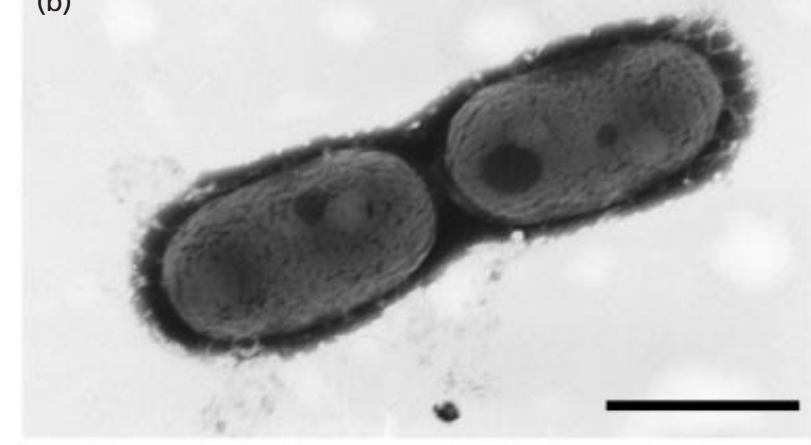

Fig. 1. (a) Phase-contrast micrographs (bar, $10 \mu \mathrm{m}$ ) and (b) electron micrographs of negatively stained cells (bar, $1 \mu \mathrm{m}$ ), showing general cell morphology of strain $\mathrm{HS}^{-\mathrm{AP}^{\top}}{ }^{\top}$.

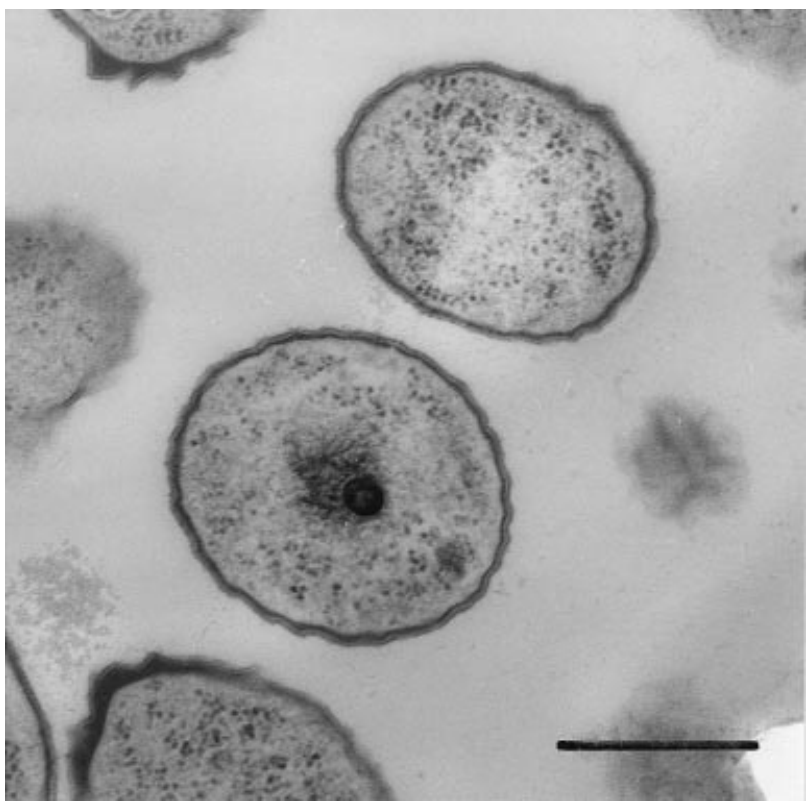

Fig. 2. Thin-section electron micrographs of strain $H S-A P 3^{\top}$. Bar, $0.5 \mu \mathrm{m}$.

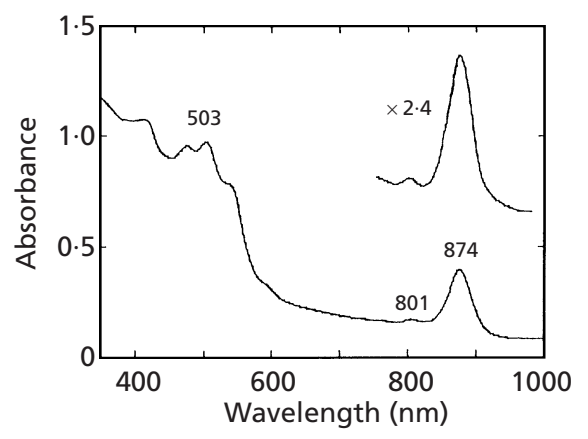

Fig. 3. Absorption spectrum of a sonicated cell extract from strain HS-AP3'.

of the Gram-negative membrane (Fig. 2). We could not find any type of intracytoplasmic membrane systems in these cells. The cells frequently contained one or two electron-dense granules which might be polyphosphate granules.

\section{Photopigment production}

Spectroscopic experiments showed that the ultrasonic cell extracts of the isolates grown in darkness had absorption maxima at 474-476, 502-503, 545 (shoulder), 590 (shoulder), 801 and 873-874 nm (Fig. 3). Also, the acetone:methanol extracts had absorption maxima at 386, 466-467 (shoulder), 494-495, 525-526 and $770 \mathrm{~nm}$ (data not shown). These spectroscopic data indicate the presence of $\mathrm{Mg}-\mathrm{BChl} a$ and carotenoids. The very low absorption peak at around $800 \mathrm{~nm}$ compared to the peak at $873-874 \mathrm{~nm}$ suggests 


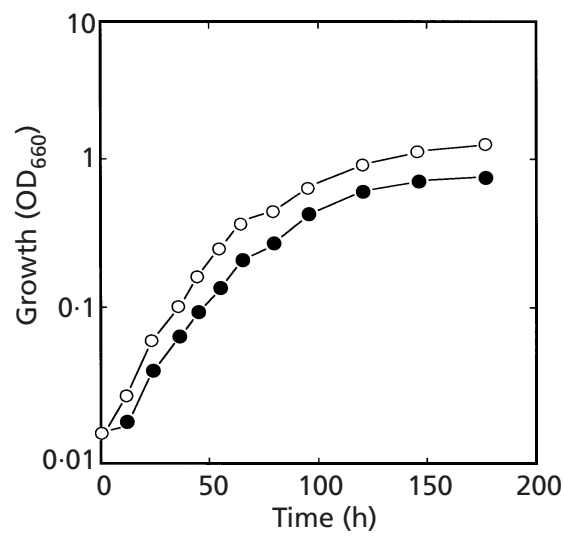

Fig. 4. Time-course of aerobic growth of strain $H S-A P 3^{T}$ in GNYS medium in the dark (filled circles) and in the light (open circles).

that the isolates contain the photosynthetic reaction centre and core light-harvesting complexes, but lack peripheral antenna complexes.

HPLC analyses of the acetone:methanol extracts demonstrated the presence of $\mathrm{Mg}-\mathrm{BChl} a$ and spirilloxanthin as the main component of BChls and carotenoids, respectively. When the cells were grown in the presence of $1 \mathrm{mM}$ zinc sulfate, an additional photopigment, $\mathrm{Zn}-\mathrm{BChl} a$, occurred in trace amounts $(1-2 \%$ of the peak area of $\mathrm{Mg}-\mathrm{BChl} a$ ) (data not shown). The isolates also contained a considerable amount of a polar carotenoid component which hardly migrated on silica-gel TLC with benzene:acetone $(1: 1, \mathrm{v} / \mathrm{v})$ as the developing solvent. The chemical structure of this carotenoid is possibly new and will be reported elsewhere.

Like the situation in many other species of aerobic BChl-containing bacteria (Shimada, 1995; Yurkov \& Beatty, 1998), aerobic and dark conditions were most favourable for $\mathrm{BChl}$ production by the isolates. The $\mathrm{BChl} a$ content of the isolates ranged from 35 to $90 \mathrm{nmol}$ (g dry wt cells $)^{-1}$. BChl production was repressed completely by continuous illumination.

\section{Effects of light and pH on growth}

The new isolates grew well under aerobic conditions with shaking but never exhibited anaerobic growth even if they were exposed to light. They showed a doubling time of $11-13 \mathrm{~h}$ when grown in GNYS medium in darkness. Continuous incandescent illumination stimulated aerobic growth of the isolates significantly, provided that the precultures were grown in darkness. The growth yield was $1 \cdot 5$ - to $1 \cdot 8$-fold higher in illuminated cultures than in dark cultures (Fig. 4). For example, illuminated and dark cultures after $7 \mathrm{~d}$ incubation had an $\mathrm{OD}_{600}$ of 1.05 and 0.70 , respectively. Light-stimulated aerobic growth has been reported in some aerobic BChl-containing bacteria

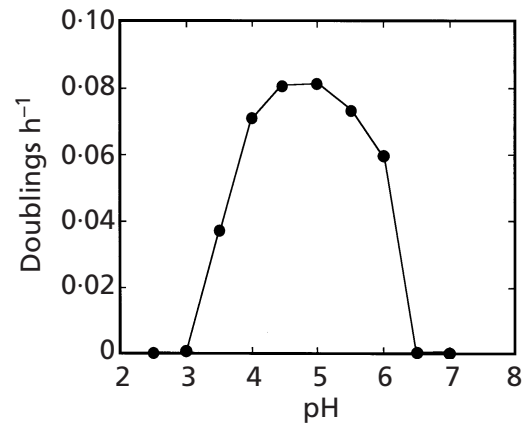

Fig. 5. Effect of $\mathrm{pH}$ on growth of strain $\mathrm{HS}-\mathrm{AP}^{\top}$.

Table 1. Carbon-source utilization by the isolates

Symbols: ++ , good growth $\left(0 \cdot 5>\mathrm{OD}_{660}\right) ;+$, moderate growth $\left(\mathrm{OD}_{660}=0 \cdot 1-0 \cdot 5\right) ;(+)$, poor growth $\left(\mathrm{OD}_{660}=\right.$ $0 \cdot 05-0 \cdot 1) ;+/-$, little, or ambiguous, growth; - , no growth. No strains grew with inositol, lactose, maltose, sucrose, butanol, methanol, propanol, acetate $(0.05 \%)$, benzoate $(0.05 \%)$, butyrate $(0.05 \%)$, citrate, formate, propionate, alanine, asparagine, aspartate, glutamate or leucine.

\begin{tabular}{|c|c|c|c|c|}
\hline \multirow[t]{2}{*}{ Substrate } & \multicolumn{4}{|c|}{ Growth response of: } \\
\hline & HS-AP3 ${ }^{T}$ & HS-AP4 & HS-AP16 & YO-704 \\
\hline \multicolumn{5}{|l|}{ Sugar/sugar alcohol } \\
\hline L-Arabinose & $+/-$ & $(+)$ & $(+)$ & $+/-$ \\
\hline D-Fructose & $+1-$ & $(+)$ & $+/-$ & $+/-$ \\
\hline D-Galactose & + & ++ & $(+)$ & + \\
\hline D-Glucose & $(+)$ & $(+)$ & $(+)$ & $(+)$ \\
\hline Glycerol & + & + & + & + \\
\hline D-Mannitol & $(+)$ & $(+)$ & $+/-$ & $(+)$ \\
\hline D-Mannose & - & $+/-$ & $+/-$ & - \\
\hline D-Sorbitol & + & + & $(+)$ & + \\
\hline D-Xylose & + & + & + & + \\
\hline \multicolumn{5}{|l|}{ Alcohol } \\
\hline Ethanol & + & + & + & + \\
\hline \multicolumn{5}{|l|}{ Organic acid } \\
\hline Fumarate & + & + & + & + \\
\hline Gluconate & ++ & ++ & ++ & ++ \\
\hline Lactate & + & ++ & + & ++ \\
\hline Malate & ++ & ++ & ++ & ++ \\
\hline Pyruvate & ++ & ++ & ++ & ++ \\
\hline Succinate & + & + & + & + \\
\hline \multicolumn{5}{|c|}{ Amino acids and others } \\
\hline Casamino acids & $+/-$ & $+/-$ & $+/-$ & $+/-$ \\
\hline Peptone & $+/-$ & $+/-$ & $+/-$ & $+/-$ \\
\hline Yeast extract & $(+)$ & $(+)$ & $(+)$ & $(+)$ \\
\hline
\end{tabular}

(Harashima et al., 1987; Yurkov \& Van Gemerden, 1993). Illumination also had positive effects on the viability of the isolates under starvation conditions, as is the case in other aerobic BChl-producing bacteria (Shiba, 1984). 


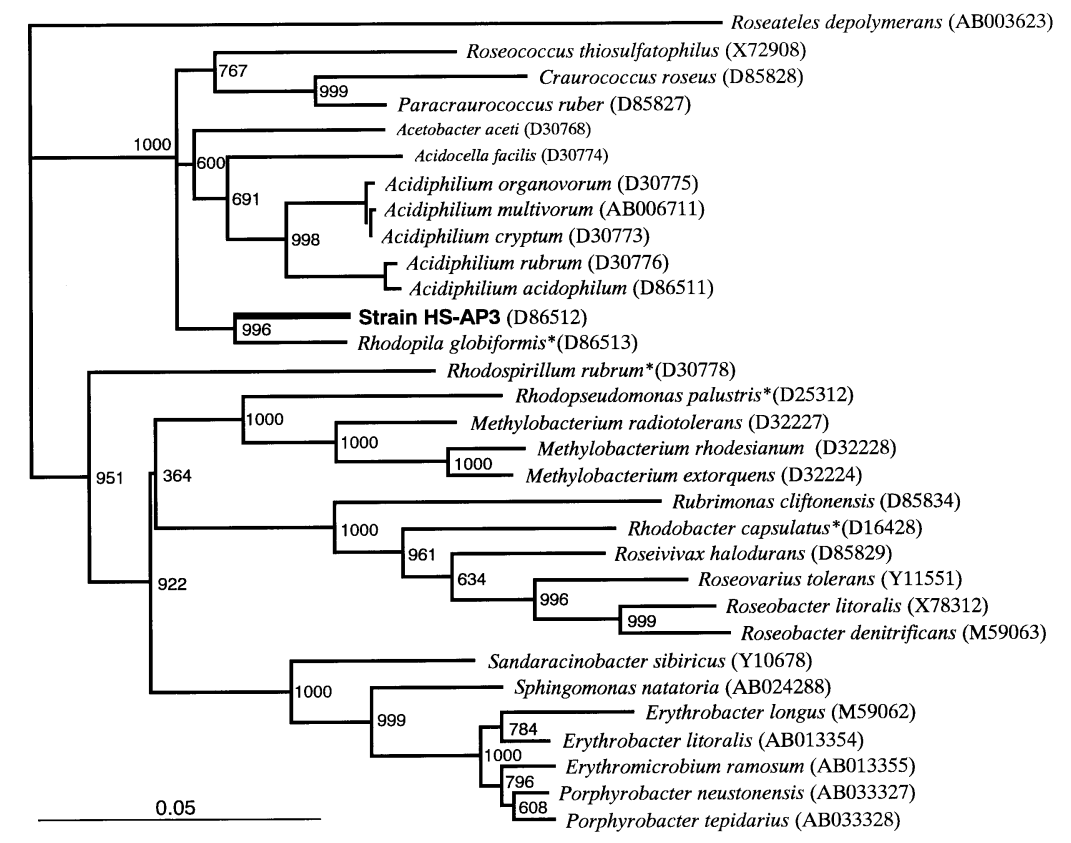

Fig. 6. Distance-matrix tree showing phylogenetic affiliations of the new isolate HS-AP3 ${ }^{\top}$, other aerobic and anaerobic photosynthetic bacteria and their nonphotosynthetic relatives of the $\alpha$-subclass of Proteobacteria, based on 16S rDNA sequences. Roseateles depolymerans ( $\beta$ subclass) was used as a member of outgroups to root the tree. Bootstrap values obtained with 1000 bootstrap resamplings are given at branching points of interest. Anaerobic phototrophs are asterisked and non-photosynthetic relatives are shown in small letters. The DDBJ/EMBL/GenBank accession numbers of the 16S rDNA sequences used are shown in parentheses. Bar, 5 nucleotide substitutions per 100 nucleotides.

Table 2. DNA base composition of, and DNA-DNA relatedness between, the new isolates and related organisms

\begin{tabular}{|c|c|c|c|}
\hline \multirow[t]{2}{*}{ Test organism } & \multirow[t]{2}{*}{$\begin{array}{c}\text { DNA G }+\mathrm{C} \\
\text { content }(\mathrm{mol} \%)\end{array}$} & \multicolumn{2}{|c|}{$\begin{array}{l}\text { Hybridization (\%) to } \\
\text { labelled DNA from: }\end{array}$} \\
\hline & & $\mathbf{H S}-\mathbf{A P 3} 3^{\mathrm{T}}$ & $\begin{array}{l}\text { R. globiformis } \\
\text { DSM } 161^{\mathrm{T}}\end{array}$ \\
\hline \multicolumn{4}{|l|}{ Isolate } \\
\hline HS-AP $3^{T}$ & $69 \cdot 3$ & 100 & 7 \\
\hline HS-AP4 & $69 \cdot 1$ & 83 & 4 \\
\hline HS-AP16 & $69 \cdot 8$ & 81 & 9 \\
\hline YO-704 & $69 \cdot 6$ & 93 & 6 \\
\hline Rhodopila globiformis DSM $161^{\mathrm{T}}$ & $65 \cdot 1 *$ & 6 & 100 \\
\hline Acidisphaera cryptum AТCC $33463^{\mathrm{T}}$ & $67 \cdot 1 \dagger$ & 2 & 2 \\
\hline Acidisphaera rubrum ATCC $35905^{\mathrm{T}}$ & $63 \cdot 6 \dagger$ & 2 & 2 \\
\hline
\end{tabular}

* Cited from Pfennig (1974).

$\dagger$ Cited from Wakao et al. (1994).

The four isolates grew in a $\mathrm{pH}$ range of 3.5 to 6.0 and failed to grow at $\mathrm{pH} 3.0$ and 6.5 . As an example, the growth response of strain $\mathrm{HS}-\mathrm{AP} 3^{\mathrm{T}}$ to different $\mathrm{pH}$ conditions is shown in Fig. 5. The pH optimum was $4 \cdot 5-5 \cdot 0$. Thus, the isolates were obligately acidophilic.

\section{Physiological and biochemical characteristics}

The new isolates were aerobic chemo-organotrophic acidophiles that had a respiratory-type of metabolism, with oxygen as the terminal electron acceptor. Anaerobic growth with nitrate was not found. Nitrate was not reduced to nitrite. Neither sulfide, elemental sulfur, thiosulfate nor $\mathrm{Fe}^{2+}$ served as the electron donor for chemolithotrophic growth. The optimum temperature for growth was $30-35^{\circ} \mathrm{C}$. Growth occurred in the presence of $0-1 \% \mathrm{NaCl}$ and was inhibited by $3 \%$ $\mathrm{NaCl}$. Catalase and cytochrome oxidase were produced. Hydrolysis of starch, Tween 80 or casein was negative.

The results of carbon nutrition tests are shown in Table 1. All isolates grew well with gluconate, lactate, malate and pyruvate. Moderate growth was observed with xylose, galactose, glycerol, sorbitol, ethanol and some intermediates of the tricarboxylic acid cycle. Little or no growth occurred with lower fatty acids, citrate, benzoate, amino acids, peptone and Casamino acids. 


\section{Quinone composition}

HPLC experiments indicated that ubiquinone-10 accounted for $98-99 \%$ of the total quinone contents of the new isolates. The remainder detected was ubiquinone-9. No other quinone ring groups, such as menaquinones or rhodoquinones, were detected.

\section{Phylogenetic analyses}

The phylogenetic positions of the new isolates were evaluated by studying the 16S rDNA sequence information. We determined nearly full-length $16 \mathrm{~S}$ rDNA sequences from strains HS-AP3 ${ }^{\mathrm{T}}$ and YO-704 and $R$. globiformis DSM $161^{\mathrm{T}}$. Partial 16S rDNA sequences (approx. 700 bases) of strains HS-AP4 and HS-AP16 were also determined. The 16S rDNA sequences of the new isolates were identical in the compared regions. A neighbour-joining phylogenetic tree was constructed on the basis of the distancematrix data of the test strains and several reference bacteria (Fig. 6). The new isolates clustered in a major acidophilic group of the Proteobacteria containing species of the genera Acetobacter, Acidicella, Acidiphilium and Rhodopila. The 16S rDNA sequences of the isolates were most similar to the sequence of $R$. globiformis at a level of sequence similarity of $95.0 \%$ (corrected distance $=0.0455$ ).

The results of DNA base ratio determination and DNA-DNA pairing studies are shown in Table 2. The DNA base ratios of the new isolates ranged from $69 \cdot 1$ to $69.7 \mathrm{~mol} \%$ and levels of DNA-DNA hybridization greater than $81 \%$ were found among them. These results, together with phenotypic data and $16 \mathrm{~S}$ rDNA sequence information, indicate that the new isolates form a genetically coherent group at the species level.

\section{DISCUSSION}

The discovery of $\mathrm{Zn}-\mathrm{BChl} a$ in the acidophilic bacteria of the genus Acidiphilium (Wakao et al., 1996; Hiraishi et al., 1998) has not only provided a new insight into bacterial photosynthesis but has also raised the question as to whether this pigment is essential for photosynthesis in such acidophilic bacteria as those capable of growing at $\mathrm{pH} 4.0$ and below. Since the BChl dimers, called the special pair in the photosynthetic reaction centre, are located near the periplasmic side of the membrane, they may be affected by external $\mathrm{pH}$. This may be a plausible reason why Acidiphilium species contain $\mathrm{Zn}-\mathrm{BChl} a$ rather than $\mathrm{Mg}$-BChl $a$ as the main photopigment. The former pigment is much more stable than the latter under acidic conditions (Wako et al., 1996; Kobayashi et al., 1998). The above-noted question motivated us to survey phototrophic acidophiles other than Acidiphilium species in strongly acidic environments. As reported here, our surveys have resulted in the isolation of the aerobic phototrophic acidophiles that are able to grow in a $\mathrm{pH}$ range of $3 \cdot 5-6 \cdot 0$, with $\mathrm{pH}$ optima at 4.5-5.0. However, unlike Acidiphilium species, the new isolates do not produce $\mathrm{Zn}-\mathrm{BChl} a$ but instead have $\mathrm{Mg}-\mathrm{BChl} a$ as the major component. This finding not only indicates that there are major phenotypic differences between the new acidophilic isolates and members of the genus Acidiphilium but also suggests that the occurrence of $\mathrm{Zn}-\mathrm{BChl} a$ is not always essential for photosynthesis in obligately acidophilic bacteria. However, since the isolates are not so strongly acidophilic as Acidiphilium species, the relationship between $\mathrm{Zn}-\mathrm{BCh}$-involved bacterial photosynthesis and acidic environments is still a major subject of study.

The phylogenetic analysis based on the 16S rDNA sequence information has demonstrated that the new isolates form a major cluster with members of some genera of aerobic and anaerobic phototrophic bacteria including Acidiphilium, Craurococcus, Paracraurococcus, Roseococcus and Rhodopila. Morphologically, our isolates are similar to species of the genera of aerobic phototrophic bacteria, Craurococcus, Paracraurococcus and Roseococcus. However, these established genera of aerobic BChl-containing bacteria are not acidophilic (Yurkov et al., 1994; Saitoh et al., 1998). In this respect, and in terms of some other phenotypic traits, our isolates are clearly distinguishable from the previously known genera showing coccoid forms (Table 3). The nearest phylogenetic relative to the new isolates is the anaerobic phototrophic bacterium $R$. globiformis. The isolates are similar to $R$. globiformis in terms of cell morphology and the preference for growth under acidic conditions. However, $R$. globiformis grows best under anaerobic/ light conditions, whereas our isolates never grow anaerobically in the light. Also, there are major differences between the isolates and $R$. globiformis in chemotaxonomic characteristics, including quinone profiles and carotenoid composition.

Therefore, although the new isolates have a relatively close phylogenetic relationship to $R$. globiformis, it is our conclusion that the isolates should be classified into a new genus separate from the genus Rhodopila as well as from all established genera of the aerobic BChlcontaining bacteria. We propose the name Acidisphaera rubrifaciens gen. nov., sp. nov. for the new isolates. The differential characteristics of Acidisphaera and phylogenetically related genera of phototrophic bacteria are shown in Table 3 .

\section{Description of Acidisphaera gen. nov.}

Acidisphaera (A.ci.di.sphae'ra. M.L. n. acidum an acid; M.L. fem. n. sphaera a sphere; M.L. fem. n. Acidisphaera acid-requiring coccoid micro-organism).

Cells are non-motile cocci and coccobacilli. Nonspore-forming and unencapsulated. Gram-negative. Obligately aerobic chemo-organotroph and facultative photo-organotroph. Light stimulates aerobic growth and viability. Does not grow anaerobically in the light. Produces bacteriochlorophyll $a$ and carotenoids. Mesophilic and obligately acidophilic. Grows between $\mathrm{pH} 3.5$ and $\mathrm{pH}$ 6.0. No growth occurs in the presence 
Table 3. Differential characteristics of Acidisphaera gen. nov. and phylogenetically related genera of phototrophic bacteria

Information on Acidiphilium is based on Kishimoto et al. (1995) and Hiraishi et al. (1998), information on Craurococcus and Paracraurococcus is based on Saitoh et al. (1998), information on Roseococcus is based on Yurkov et al. (1994) and information on Rhodopila is based on Pfennig (1974), Imhoff \& Bias-Imhoff (1985) and this study.

\begin{tabular}{|c|c|c|c|c|c|c|}
\hline Characteristic & $\begin{array}{c}\text { Acidisphaera } \\
\text { gen. nov. }\end{array}$ & Acidiphilium & Craurococcus & Paracraurococcus & Roseococcus & Rhodopila \\
\hline Cell shape & Cocci, short rods & Rods & Cocci & Cocci & Cocci & Cocci \\
\hline Cell diameter & $0 \cdot 7-0 \cdot 9$ & $0 \cdot 5-0 \cdot 7$ & $0 \cdot 8-2 \cdot 0$ & $0 \cdot 8-1 \cdot 5$ & $0 \cdot 9-1 \cdot 3$ & $1 \cdot 6-1 \cdot 8$ \\
\hline Motility & - & + & - & - & + & + \\
\hline Colour of colonies & Salmon-pink & Pink, red & Pink & Red & Pink & Purple-red \\
\hline $\mathrm{Zn}-\mathrm{BChl}$ as main pigment & - & + & $-*$ & $-*$ & $-*$ & $-*$ \\
\hline Near IR peak for BChl $a$ & 874 & 864 & 872 & 856 & 855 & 865 \\
\hline Anaerobic phototrophy & - & - & - & - & - & + \\
\hline Optimum $\mathrm{pH}$ for growth & $4 \cdot 5-5 \cdot 0$ & $3 \cdot 0-3 \cdot 5$ & $7 \cdot 5$ & $6 \cdot 6-6 \cdot 8$ & & $4 \cdot 8-5 \cdot 0$ \\
\hline Growth at $\mathrm{pH} 7$ & - & - & + & + & & - \\
\hline Quinone(s) & Q-10 & Q-10 & Q-10 & Q-10 & Q-10 & $\begin{array}{c}\text { Q-9(10), } \\
\text { MK-9(10), } \\
\text { RQ-9(10) }\end{array}$ \\
\hline DNA G $+\mathrm{C}$ content $(\mathrm{mol} \%)$ & $69 \cdot 1-69 \cdot 8$ & $62 \cdot 9-68 \cdot 3$ & $70 \cdot 5$ & $70-71$ & $70 \cdot 4$ & $66 \cdot 3$ \\
\hline
\end{tabular}

* A. Hiraishi (unpublished data).

of $3 \% \mathrm{NaCl}$. Catalase- and oxidase-positive. Grows with a number of simple organic compounds as electron donors and carbon sources. Growth on complex media containing peptone is poor. Neither sulfide, elemental sulfur, thiosulfate nor $\mathrm{Fe}^{2+}$ serve as the electron donor for chemolithotrophic growth. Ubiquinone-10 is present as the major respiratory quinone. The $\mathrm{G}+\mathrm{C}$ content of the genomic DNA ranges from $69 \cdot 1$ to $69 \cdot 8 \mathrm{~mol} \%$. $16 \mathrm{~S}$ rDNA sequence information places the genus in the $\alpha$-subclass of the Proteobacteria, with Rhodopila as its phylogenetic neighbour. The type species is Acidisphaera rubrifaciens.

\section{Description of Acidisphaera rubrifaciens sp. nov.}

Acidisphaera rubrifaciens (rub.ri.fa'ci.ens. L. adj. ruber red; L. v. facio to make; M.L. part. adj. rubrifaciens red-producing).

Cells are Gram-negative non-motile cocci or coccobacilli measuring $0 \cdot 7-1.0 \mu \mathrm{m}$ wide and $0.8-1.2 \mu \mathrm{m}$ long. Any type of intracytoplasmic membrane system is absent. Polyphosphate granules are present. Colonies on solidified media are circular, smooth, convex, salmon-pink to red and reach $2 \mathrm{~mm}$ in diameter after 1 week incubation. Cell membranes have absorption maxima at 474-476, 502-503, 545, 590, 801 and $873-874 \mathrm{~nm}$. Acetone:methanol extracts from cells have absorption maxima at 386, 466-467, 494-495, 525-526 and $770 \mathrm{~nm}$. Spirilloxanthin and an unknown polar pigment are the major carotenoids. The temperature range for growth is $20-40{ }^{\circ} \mathrm{C}$ (optimum $30-35{ }^{\circ} \mathrm{C}$ ). The $\mathrm{pH}$ optimum for growth is $4 \cdot 5-5 \cdot 0$. Nitrate is not reduced to nitrite. Hydrolysis of starch, casein or Tween 80 is absent. Gluconate, lactate, malate and pyruvate are good carbon sources. Other carbon sources that support growth are galactose, glucose, D-xylose, glycerol, mannitol, sorbitol, fumarate, malate, succinate and yeast extract. Little or no growth occurs with L-arabinose, fructose, mannose, lactose, sucrose, inositol, butanol, ethanol, methanol, propanol, formate, acetate, propionate, butyrate, citrate, benzoate, Casamino acids and peptone. The $\mathrm{G}+\mathrm{C}$ content of the genomic DNA ranges from $69 \cdot 1$ to $69.8 \mathrm{~mol} \%$. The habitats are strongly acidic mineral environments, including acidic hot springs and pyritic mine drainage. The type strain is strain HS-AP3 ${ }^{\mathrm{T}}$, which has been deposited with the Japan Collection of Microorganisms, RIKEN, Wako, Japan, as JCM $10600^{\mathrm{T}}$.

\section{ACKNOWLEDGEMENTS}

We are grateful to Yuri Higuchi, Department of Ecological Engineering, Toyohashi University of Technology, for her technical assistance. This work was supported, in part, by a grant-in-aid from the Ministry of Education, Science, Culture and Sports, Japan (no. 09309008).

\section{REFERENCES}

Brosius, J., Palmer, J. L., Kennedy, J. P. \& Noller, H. F. (1978). Complete nucleotide sequence of a $16 \mathrm{~S}$ ribosomal RNA gene from Escherichia coli. Proc Natl Acad Sci USA 75, 4801-4805.

Clayton, R. K. (1963). Toward the isolation of a photochemical reaction center in Rhodopseudomonas sphaeroides. Biochim Biophys Acta 75, 312-323.

Felsenstein, J. (1985). Confidence limits on phylogenies: an approach using the bootstrap. Evolution 39, 783-791. 
Harashima, K., Kwazoe, K., Yoshida, I. \& Kamata, H. (1987). Light-stimulated aerobic growth of Erythrobacter species Och 114. Plant Cell Physiol 28, 365-374.

Hiraishi, A. \& Kitamura, H. (1984). Distribution of phototrophic purple nonsulfur bacteria in activated sludge systems and other aquatic environments. Bull Jpn Soc Sci Fish 50, 129-137.

Hiraishi, A., Hoshino, Y. \& Satoh, T. (1991). Rhodoferax fermentans gen. nov., sp. nov., a phototrophic purple nonsulfur bacterium previously referred to as the 'Rhodocyclus gelatinosus-like' group. Arch Microbiol 155, 330-336.

Hiraishi, A., Shin, Y. K., Ueda, Y. \& Sugiyama, J. (1994). Automated sequencing of PCR-amplified 16S rDNA on 'Hydrolink' gels. J Microbiol Methods 19, 145-154.

Hiraishi, A., Kamagata, Y. \& Nakamura, K. (1995a). Polymerase chain reaction amplification and restriction fragment length polymorphism analysis of $16 \mathrm{~S}$ rRNA genes from methanogens. J Ferment Bioeng 79, 523-529.

Hiraishi, A., Urata, K. \& Satoh, T. (1995b). A new genus of marine budding phototrophic bacteria, Rhodobium gen. nov., which includes Rhodobium orientis sp. nov., and Rhodobium marinum comb. nov. Int J Syst Bacteriol 45, 226-234.

Hiraishi, A., Ueda, Y., Ishihara, J. \& Mori, T. (1996). Comparative lipoquinone analysis of influent sewage and activated sludge by high-performance liquid chromatography and photodiode array detection. J Gen Appl Microbiol 42, 457-469.

Hiraishi, A., Nagashima, K. V. P., Matsuura, K., Shimada, K., Takaichi, S., Wakao, N. \& Katayama, Y. (1998). Phylogeny and photosynthetic features of Thiobacillus acidophilus and related acidophilic bacteria: its transfer to the genus Acidiphilium as Acidiphilium acidophilum comb. nov. Int J Syst Bacteriol 48, 1389-1398.

Imhoff, J. F. \& Bias-Imhoff, U. (1995). Lipids, quinones and fatty acids of anoxygenic phototrophic bacteria. In Anoxygenic Photosynthetic Bacteria, pp. 179-205. Edited by R. E. Blankenship, M. T. Madigan \& C. E. Bauer. Dordrecht: Kluwer.

Katayama-Fujimura, Y., Komatsu, Y., Kuraishi, H. \& Kaneko, T. (1984). Estimation of DNA base composition by high performance liquid chromatography of its nuclease P1 hydrolysate. Agric Biol Chem 48, 3169-3172.

Kimura, M. (1980). A simple method for estimating evolutionary rates of base substitution through comparative studies of nucleotide sequences. $J$ Mol Evol 16, 111-120.

Kishimoto, H. \& Tano, T. (1987). Acidophilic heterotrophic bacteria isolated from acidic mine drainage, sewage, and soils. J Gen Appl Microbiol 33, 11-25.

Kishimoto, N., Kosako, Y., Wakao, N., Tano, T. \& Hiraishi, A. (1995). Transfer of Acidiphilium facilis and Acidiphilium aminolytica to the genus Acidocella gen. nov., and emendation of the genus Acidiphilium. Syst Appl Microbiol 18, 85-91.

Kobayashi, M., Yamamura, M., Akiyama, M., Kise, H., Inoue, K., Hara, M., Wakao, N., Yahara, K. \& Watanabe, T. (1998). Acid resistance of Zn-bacteriochlorophyll $a$ from an acidophilic bacterium Acidiphilium rubrum. Anal Sci 14, 1149-1152.

Labrenz, M., Collins, M. D., Lawson, P. A., Tindall, B. J., Schumann, P. \& Hirsch, P (1999). Roseovarius tolerans gen. nov., sp. nov., a budding bacterium with variable bacteriochlorophyll a production from hypersaline Ekho Lake. Int $J$ Syst Bacteriol 49, 137-147.
Marmur, J. (1961). A procedure for the isolation of deoxyribonucleic acid from micro-organisms. J Mol Biol 3, 208-218.

Page, R. D. M. (1997). TREEVIEW program version 1.5.1. University of Glasgow, UK

Pfennig, N. (1974). Rhodopseudomonas globiformis sp. n., a new species of the Rhodospirillaceae. Arch Microbiol 100, 197-206.

Saitoh, S., Suzuki, T. \& Nishimura, Y. (1998). Proposal of Craurococcus roseus gen. nov., sp. nov. and Paracraurococcus ruber gen. nov., sp. nov., novel aerobic bacteriochlorophyll $a$ containing bacteria from soil. Int J Syst Bacteriol 48, 1043-1047.

Saitou, N. \& Nei, M. (1987). The neighbor-joining method: a new method for reconstructing phylogenetic trees. Mol Biol Evol 4, 406-425.

Shiba, T. (1984). Utilization of light energy by the strictly aerobic bacterium Erythrobacter sp. Och114. J Gen Appl Microbiol 30, 239-244.

Shimada, K. (1995). Aerobic anoxygenic phototrophs. In Anoxygenic Photosynthetic Bacteria, pp. 105-122. Edited by R. E. Blankenship, M. T. Madigan \& C. E. Bauer. Dordrecht: Kluwer.

Suyama, T., Shigematsu, T., Takaichi, S., Nodasaka, Y., Fujikawa, S., Hosoya, H., Tokiwa, Y., Kanagawa, T. \& Hanada, S. (1999). Roseateles depolymerans gen. nov., sp. nov., a new bacteriochlorophyll $a$-containing obligate aerobe belonging to the $\beta$ subclass of the Proteobacteria. Int J Syst Bacteriol 49, 449-457.

Suzuki, T., Muroga, Y., Takahama, M., Shiba, T. \& Nishimura, Y. (1999). Rubrimonas cliftonensis gen. nov., sp. nov., an aerobic bacteriochlorophyll-containing bacterium isolated from a saline lake. Int J Syst Bacteriol 49, 201-205.

Thompson, J. D., Higgins, D. G. \& Gibson, T. J. (1994). CLUSTAL $\mathrm{W}$ : improving the sensitivity of progressive multiple sequence alignment through sequence weighting, position-specific gap penalties and weight matrix choice. Nucleic Acids Res 22 , 4673-4680.

Wakao, N., Nagasawa, N., Matsuura, T., Matsukura, H., Matsumoto, T., Hiraishi, A., Sakurai, Y. \& Shiota, H. (1994). Acidiphilium multivorum sp. nov., an acidophilic chemoorganotrophic bacterium from pyritic acid mine drainage. J Gen Appl Microbiol 40, 143-159.

Wakao, N., Yokoi, N., Isoyama, N. \& 8 other authors (1996). Discovery of natural photosynthesis using zinc-containing bacteriochlorophyll in an aerobic bacterium Acidiphilium rubrum. Plant Cell Physiol 37, 889-893.

Yurkov, V. V. \& Beatty, J. T. (1998). Anoxygenic aerobic phototrophic bacteria. Microbiol Mol Biol Rev 62, 695-724.

Yurkov, V. V. \& Van Gemerden, H. (1993). Impact of light/dark regimen on growth rate, biomass formation and bacteriochlorophyll synthesis in Erythromicrobium hydrolyticum. Arch Microbiol 159, 84-89.

Yurkov, V., Stackebrandt, E., Holmes, A. \& 7 other authors (1994). Phylogenetic positions of novel aerobic, bacteriochlorophyll acontaining bacteria and description of Roseococcus thiosulfatophilus gen. nov., sp. nov., Erythromicrobium ramosum gen. nov., and Erythrobacter litolaris sp. nov. Int J Syst Bacteriol 44, 427-434.

Yurkov, V., Krieger, S., Stackebrandt, E. \& Beatty, J. T. (1999). Citromicrobium bathyomarinum, a novel aerobic bacterium isolated from deep-sea hydrothermal vent plume waters that contains photosynthetic pigment-protein complexes. $J$ Bacteriol 181, 4517-4525. 